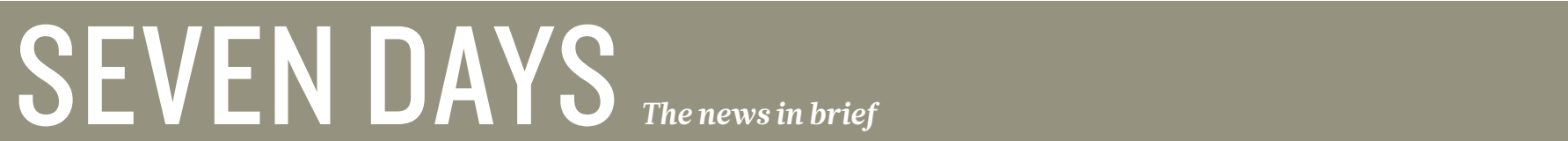

EVENTS

\section{Money for nothing}

A data organization has launched what it says is the world's first prize for publishing negative scientific results. The European College of Neuropsychopharmacology's Preclinical Data Forum says that the aim of the $€ 10,000$ (US\$ $\$ 1,600$ ) prize is to encourage researchers to publish data that don't confirm the hypothesis being tested. Such negative studies are much less likely to be published than positive results, meaning that other scientists may waste time trying to repeat the work. The call for entries - initially just for neuroscience research opened on 8 November.

\section{Bulgarian protest}

Hundreds of Bulgarian researchers took to the streets of Sofia on 1 November to demand higher wages and an increase in science funding marked out in the government's 2018 budget. Bulgaria has one of the lowest levels of research investment in the European Union. The demonstrators are threatening further protests when Bulgaria takes over the rotating EU presidency next January.

\section{Rohingya refugees}

A survey of Rohingya refugees in Bangladesh suggests that $7.5 \%$ of the children have life-threatening malnutrition. The United Nations children's charity UNICEF reported the figure on 3 November. More than 2,700 children are being treated for acute malnutrition in refugee camps, where conditions are expected to worsen because of poor sanitation and crowding. Since late August, more than 600,000 Rohingya people have fled from Myanmar to Bangladesh, following attacks by Myanmar's police.

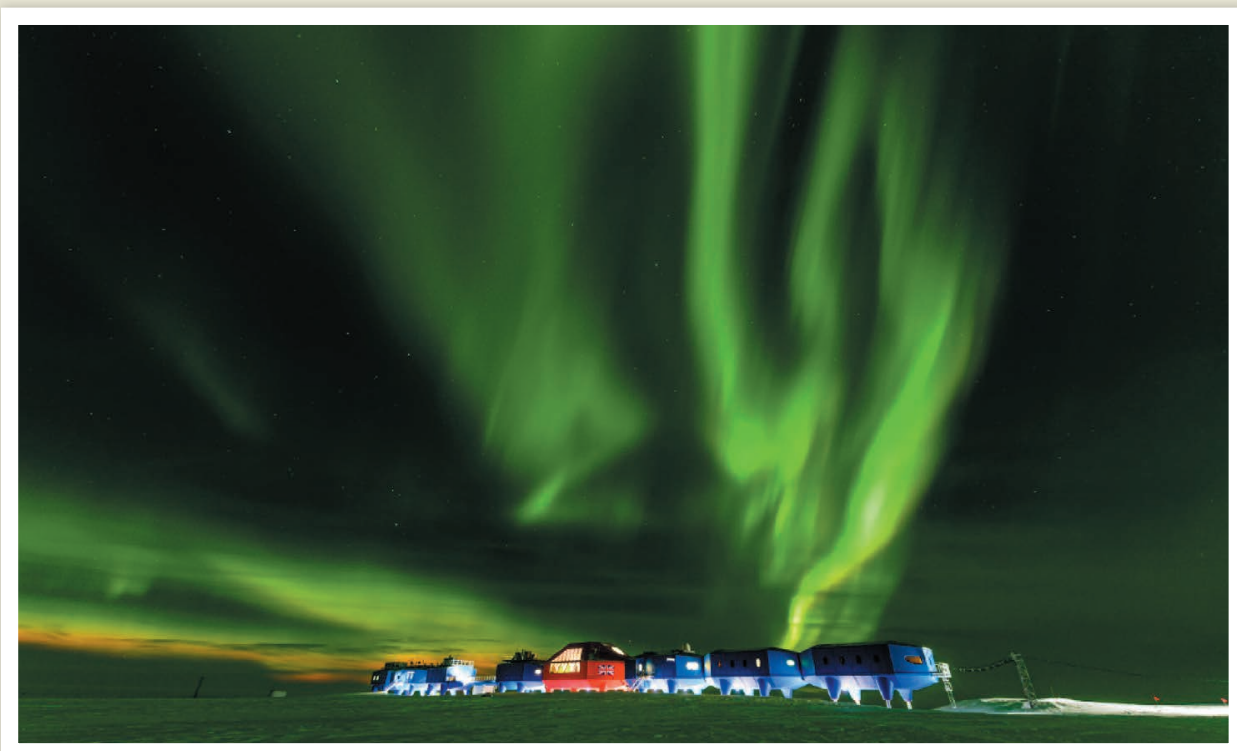

\section{Ice crack to close Antarctic base again}

For the second time in two years, the British Antarctic Survey (BAS) will close its Halley VI research station for the winter season because of an enormous crack in the floating ice shelf on which it rests. In March, operators finished moving the transportable station 23 kilometres inland from its initial 2012 location because of an ice chasm nearby. Now, another crack in the Brunt Ice Shelf, this one 50 kilometres long, is threatening the station from the other side. Halley VI will close between March and November 2018, the BAS said on 31 October, because it is too difficult to evacuate personnel quickly in winter if the crack develops further.

\section{RESEARCH}

\section{Weather forecasts}

Improving forecasts of severe weather is important, but meteorologists should also listen to social scientists to help save lives during storms, says a 1 November report from the US National Academies of Sciences, Engineering, and Medicine. It recommends that federal agencies do more to incorporate social- and behavioural-sciences research into their preparation for weather hazards. These changes might include researching people's processes for deciding how to respond to threats such as tornado or hurricane warnings, and evaluating how weather forecasters communicate with media and emergencymanagement officials to convey messages more effectively.

\section{POLICY}

\section{Antibiotic advice}

The World Health

Organization (WHO) has

recommended that animalfood industries curb the routine use of antibiotics for growth promotion and disease prevention. Healthy animals should receive the drugs only if others in the same flock or herd are diagnosed with communicable infections, the agency said in guidance published on 7 November. The recommendations were informed by a review of 179 studies; it found that the prevalence of multidrugresistant bacteria in farmed animals dropped by up to $32 \%$ in places that had cut back on antibiotic use (K. L. Tang et al. Lancet Planet. Health http://doi.org/cfxh; 2017). The evidence connecting antibiotic restrictions in farm animals to drug resistance in humans was less robust, but hinted at a similar correlation.

\section{Genetic-test rules}

The US Food and Drug Administration (FDA) is seeking to loosen its regulation of genetic tests that are marketed directly to consumers, its commissioner, Scott Gottlieb, announced on 6 November. The FDA has proposed a policy that would allow genetic-testing 
companies to submit a product to the agency for a one-time review; if approved, the company would be allowed to market more tests without further review. The proposal is open for public comment until January. The agency also said that it has decided to exempt from review tests that are used to determine whether potential parents carry disease-causing genetic mutations that could cause an inherited disorder in their children.

\section{CLIMATE}

\section{Small ozone hole}

This year's hole in the ozone layer was the smallest since 1988, NASA said on 2 November. The hole above Antarctica, which opens each September, was unusually small, owing to warm weather in the Southern Hemisphere. At its peak, the area of the hole (pictured) was almost 2 billion hectares, or roughly two and a half times the size of the contiguous United States. Scientists attribute the shrinkage to natural variation, and not to rapid healing because of human intervention, NASA said. This year, warm air above Antarctica depleted cloud cover, which is where ozone-destroying chemical reactions occur. The hole has been shrinking since the

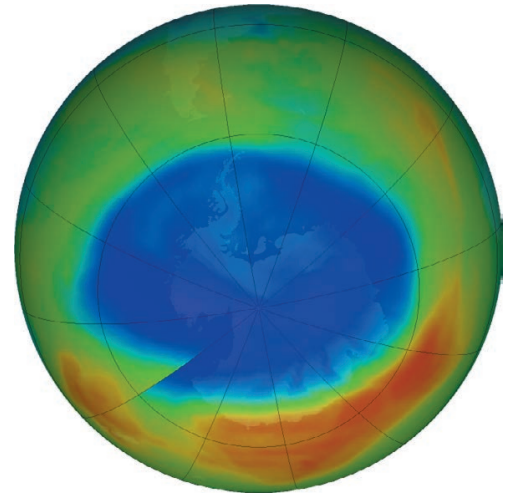

introduction in 1987 of the Montreal Protocol to phase out ozone-depleting chemicals.

\section{PUBLISHINE}

\section{Censorship in China}

Springer Nature, one of the world's largest academic publishers, has stopped readers in China from accessing some of its content. The Financial Times reported on 1 November that the publisher had blocked access to more than 1,000 articles from the websites of two of its journals, The Journal of Chinese Political Science and International Politics. The publishing house, which also owns Nature, said that the articles accounted for less than $1 \%$ of its content and had been blocked to comply with local Chinese laws. (Nature's news team is editorially independent of its publisher.) The articles included politically sensitive terms such as Tibet, Taiwan and Cultural Revolution. Some in the academic community criticized the decision, which comes two-and-a-half months after UK firm Cambridge University Press blocked access to some articles in China and then swiftly reversed its decision.

\section{Copyright battle}

The scholarly social network ResearchGate has over the past month disabled public access to 1.7 million papers on its site, according to five scientific publishers who have been tracking its activities. Early last month, the publishers formed a coalition to get ResearchGate to take down papers that breach copyright; two publishers have also filed a lawsuit against the site. The coalition says that the site has since disabled access to around $93 \%$ of its copyrighted material, although academics have re-uploaded some papers for public view. The publishers have now sent an undisclosed number of take-down notices to order the removal of remaining infringing content. ResearchGate, which is based in Berlin, declined to comment.

\section{Piracy-site lawsuit}

The American Chemical Society (ACS) has won a lawsuit against the pirate site Sci-Hub over the website's illicit dissemination of copyrighted research

\section{TREND WATCH}

The number of people who were able to access treatment for viral hepatitis $\mathrm{C}$ grew by some 1.7 million in 2016 , a $60 \%$ increase over 2015, the World Health Organization (WHO) said on 31 October. A further 2.8 million people were given lifelong treatment for hepatitis B in 2016, a $65 \%$ jump over 2015 . The WHO estimates that there were between 6 million and 10 million new cases of viral hepatitis B and C in 2015. The agency wants $80 \%$ of people diagnosed to be receiving treatment by 2030 .

\section{PROGRESS IN HEPATITIS TREATMENT}

More people are being treated for hepatitis B and C, thanks

to a global effort to eliminate the diseases.

- Hepatitis B Hepatitis C

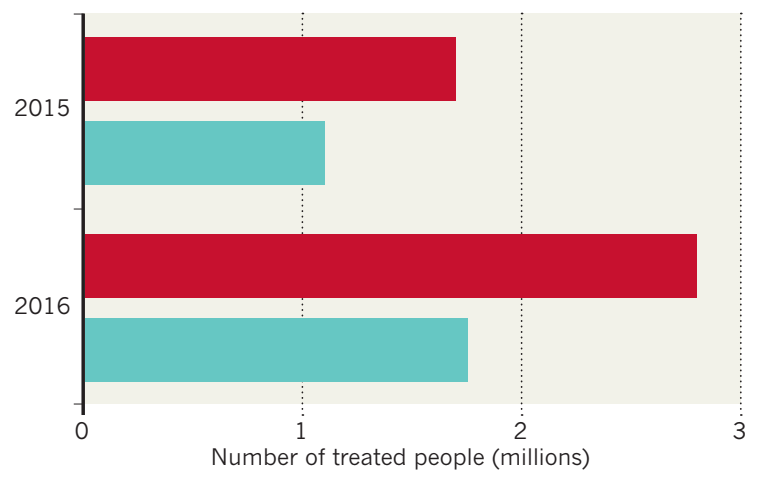

articles. On 3 November, a US court granted the ACS US $\$ 4.8$ million in damages for copyright infringement and trademark violation. The court also issued an injunction ordering Internet services that are "in active concert or participation" with Sci-Hub, including providers and search engines, to stop facilitating access to the site. Representatives of Sci-Hub, which was launched in 2011, did not appear in court to present their case.

\section{PEOPLE}

\section{Nominee withdraws}

Sam Clovis, the controversial nominee for the post of chief scientist at the US Department of Agriculture, withdrew from consideration on 2 November. The announcement came shortly after Clovis's name surfaced in the ongoing investigation into links between US President Donald Trump's election campaign and Russia. Clovis, a former conservative talk-show host and economics professor, was already a controversial pick for the chief-scientist position, which, by law, must be filled by a distinguished scientist.

\section{Science chair to quit}

Representative Lamar Smith, the controversial chair of the US House of Representatives' science committee, said on 2 November that he will retire when his term expires late next year. The Texas Republican has repeatedly questioned the science behind climate change, has sought to pare back the research portfolio of the US National Science Foundation and has launched dozens of probes into alleged wrongdoing by individual scientists and US government science agencies. The House of Representatives limits committee chairs to six years in the role, so Smith would have been forced to relinquish his post on the science panel in 2019.

\section{$\rightarrow$ NATURE.COM}

For daily news updates see:

www.nature.com/news 